\title{
Vetyperoksidia ja natriumbentsoaattia sisältävä säilöntäaine nurmirehun säilönnässä
}

\author{
Heikkilä, T. ${ }^{1)}$, Saarisalo, E. ${ }^{1,2)}$ ja Khalili, H. ${ }^{1)}$ \\ ${ }^{1)}$ Maa-ja elintarviketalouden tutkimuskeskus, MTT / Kotieläintuotannon tutkimus, 31600 Jokioinen, \\ etunimi.sukunimi@mtt.fi \\ ${ }^{2)}$ Nykyinen osoite: Maa- ja metsätalousministeriö, Elintarvike- ja terveysosasto, PL 30, 00023 Valtio- \\ neuvosto,etunimi.sukunimi@mmm.fi
}

\section{Tiivistelmä}

Säilörehun teossa tavoitteena on ruohon rehuarvon säilyminen mahdollisimman hyvänä, mikä tarkoittaa hyvää käymislaatua, pieniä ravintoainetappioita ja hyvää aerobista stabiilisuutta siilon/paalin avaamisen jälkeen. Tämän tutkimuksen tavoitteena oli selvittää vetyperoksidia ja natriumbentsoaattia sisältävän säilöntäaineen vaikutusta lievästi ja pitkälle esikuivatun nurmisäilörehun käymislaatuun ja aerobiseen stabiilisuuteen.

Koesäilörehut tehtiin timotei-nurminadan (Phleum pratense - Festuca pratensis) ensimmäisestä sadosta, lievästi ja pitkälle esikuivatusta ruohosta kuiva-ainetavoitteiden ollessa 25-30 \% ja 40-50 \% (KA1 ja KA2). Nurmi niitettiin niittomurskaimella karholle, esikuivattiin ja korjattiin tarkkuussilppurilla ilman säilöntäainetta. Ruohot säilöttiin koesiiloihin (KA1: 7,0 kg/siilo ja KA2: 4,5 kg/siilo) ilman säilöntäainetta, muurahaishapolla (85 \%, w/w), 5 l/t ja vetyperoksidin ja natriumbentsoaatin vesiliuoksella, $5 \mathrm{l} / \mathrm{t}$ (Solvay $\mathrm{H}_{2} \mathrm{O}_{2}$ Forage nurmirehun säilöntäliuos, valmistaja Solvay Chemicals Finland Oy). Koeliuos sisälsi 19,5 \% (w/w) vetyperoksidia $\left(\mathrm{H}_{2} \mathrm{O}_{2}\right), 15 \%(\mathrm{w} / \mathrm{v})$ natriumbentsoaattia ja 0,5 \% (w/v) fosfonaattistabilointiaineita. Kutakin säilöntäkäsittelyä tehtiin kolme rinnakkaista siiloa. Siilot avattiin 110-138 vuorokauden kuluttua säilönnästä, jolloin määritettiin säilörehun käymislaatu ja aerobinen stabiilisuus seuraamalla rehun lämpötilan muutosta sen joutuessa ilman vaikutuksen alaiseksi.

Käymislaadultaan kaikki säilörehut olivat hyviä. Korkeampi kuiva-aine rajoitti selvästi käymistä kaikissa rehuissa. Kuivemmissa säilörehuissa (ka 44 \%) pH-arvo ja sokeripitoisuus olivat suuremmat ja vastaavasti maito- ja etikkahappo- ja etanolipitoisuudet sekä ammoniumtypen osuus kokonaistypestä olivat pienemmät kuin tuoreemmissa säilörehuissa (ka 29 \%). Voihappoa esiintyi säilörehuissa hyvin vähän. Vetyperoksidi-natriumbentsoaatti- säilöntäaineella ja ilman säilöntäainetta tehtyjen rehujen välillä ei ollut merkitsevää eroa säilörehun $\mathrm{pH}$ :ssa, maitohappo-, propionihappo- ja käymishappojen kokonaispitoisuudessa eikä ammoniumtypen ja liukoisen typen osuudessa kokonaistypestä. Koesäilöntäaineella tehdyssä rehussa oli hieman vähemmän sokeria ja enemmän etanolia kuin ilman säilöntäainetta tehdyssä rehussa ja vaikutus oli suurempi tuoreemmassa rehussa kuin kuivemmassa (yhdysvaikutus). Muurahaishappo rajoitti tyypillisesti rehujen käymistä lähes kaikkien parametrien kohdalla, jolloin rehussa oli alempi $\mathrm{pH}$, sokeria enemmän, käymishappoja vähemmän ja valkuainen hajonnut vähemmän kuin muilla säilöntäainekäsittelyillä.

Säilörehun aerobista stabiilisuutta vetyperoksidi-natriumbentsoaattiliuos paransi merkitsevästi ilman säilöntäainetta tehtyyn ja muurahaishapolla tehtyyn säilörehuun verrattuna vaikutuksen ollessa suurempi tuoreemmassa (ka 29 \%) rehussa kuin kuivemmassa (ka 44 \%) rehussa. Ilman säilöntäainetta tehty tuoreempi rehu alkoi lämmetä kolmen vuorokauden kuluttua siilojen avaamisesta ja koeliuoksella säilötty noin neljä vuorokautta tätä myöhemmin muurahaishapporehun lämpenemisherkkyyden ollessa niiden välillä. Aerobisen stabiilisuuden paraneminen vetyperoksidi-natriumbentsoaattiliuosta käytettäessä perustui todennäköisesti natriumbentsoaattiin.

Asiasanat: nurmisäilörehu, säilöntäaine, muurahaishappo, vetyperoksidi, natriumbentsoaatti, aerobinen stabiilisuus 


\section{Johdanto}

Säilörehun teossa tavoitteena on ruohon rehuarvon säilyminen mahdollisimman hyvänä, mikä tarkoittaa hyvää käymislaatua, pieniä ravintoainetappioita ja hyvää aerobista stabiilisuutta siilon/paalin avaamisen jälkeen. Vetyperoksidi tunnetaan desinfiointi- ja valkaisuaineena, jota käytetään muun muassa sellumassan ja tekstiilien valkaisuun sekä desinfiointiaineena lääke- ja elintarviketeollisuudessa. Vetyperoksidin teho perustuu siihen, että se hajoaa helposti vedeksi ja voimakkaasti hapettavaksi hapeksi. Natriumbentsoaatti on yleinen säilöntäaine, jota käytetään kotitaloudessa ja elintarviketeollisuudessa. Se on myös osana monissa nurmirehun säilöntäaineissa. Natriumbentsoaatilla on antimikrobisia vaikutuksia ja se on tehokkaampi matalassa pH:ssa (Woolford 1975). Natriumbentsoaatti voi myös parantaa aerobista stabiilisuutta yhdistettäessä se maitohappobakteerien kanssa (Saarisalo ym. 2006). Rehujen lisäaineet mukaan lukien säilörehun lisäaineet (säilöntäaineet), hyväksytään Euroopan yhteisön tasolla. Vetyperoksidi ja natriumbentsoaatti ovat hyväksyttyjen lisäaineiden listalla (EU lisäainerekisteri) ja niistä kuten muistakin lisäaineista, tulee jättää hakemus uudelleenarviointiin vuoden 2010 aikana. Rehun lisäaineet on sijoitettu eri luokkiin niiden käyttötarkoituksen ja ominaisuuksien perusteella ja luokkien sisällä lisäaineet jaotellaan edelleen funktionaalisiin ryhmiin tärkeimmän käyttötarkoituksen tai tärkeimpien käyttötarkoitusten mukaan. Säilörehun lisäaineet ovat Luokassa 1: Teknologiset lisäaineet, funktionaalisessa ryhmässä k: säilörehun lisäaineet (Evira 2009).

Tämän tutkimuksen tavoitteena oli selvittää yhteistyössä Berner Oy:n kanssa vetyperoksidia ja natriumbentsoaattia sisältävän säilöntäaineen vaikutusta käymislaatuun ja aerobiseen stabiilisuuteen lievästi ja pitkälle esikuivatussa nurmirehussa kuiva-ainetavoitteiden ollessa 25-30 \% ja 40-50 \%.

\section{Aineisto ja menetelmät}

Koesäilörehut tehtiin timotei-nurminatanurmen (Phleum pratense - Festuca pratensis) ensimmäisestä sadosta. Nurmi niitettiin 12.6.2007 klo 15.30 niittomurskaimella karholle, esikuivattiin ja korjattiin tarkkuussilppurilla ilman säilöntäainetta 19 tunnin kuluttua niitosta lievästi esikuivattuna (KA1) ja 45 tunnin kuluttua niitosta pitkälle esikuivattuna (KA2). Ruohot säilöttiin sylinterinmuotoisiin $12 \mathrm{dm}^{3}: \mathrm{n}$ koesiiloihin (KA1: 7,0 kg/siilo ja KA2: 4,5 kg/siilo) ilman säilöntäainetta, muurahaishapolla (85 \%, w/w), $5 \mathrm{l} / \mathrm{t}$ ja vetyperoksidin ja natriumbentsoaatin vesiliuoksella, $5 \mathrm{l} / \mathrm{t}$ (Solvay $\mathrm{H}_{2} \mathrm{O}_{2}$ Forage nurmirehun säilöntäliuos, valmistaja Solvay Chemicals Finland Oy). Koeliuos sisälsi 19,5 \% (w/w) vetyperoksidia $\left(\mathrm{H}_{2} \mathrm{O}_{2}\right), 15 \%(\mathrm{w} / \mathrm{v})$ natriumbentsoaattia ja $0,5 \%$ (w/v) fosfonaattistabilointiaineita. Jokaista säilöntäkäsittelyä kohti tehtiin kolme rinnakkaista siiloa, jotka varastoitiin huonelämpötilassa $\left(18-20^{\circ} \mathrm{C}\right)$ pimeässä. Siilot avattiin 110-138 vuorokauden kuluttua säilönnästä, yhdet rinnakkaiset kerrallaan, ja säilörehuista otettiin näytteet sekä laitettiin välittömästi aerobisen stabiilisuuden mittaukseen. Säilörehujen lämpenemisherkkyys mitattiin seuraamalla 10 päivän ajan styroxlaatikoihin laitettujen säilörehujen lämpötilan muutosta rehuun sijoitetun lämpötila-anturin avulla säilörehun joutuessa ilman vaikutuksen alaiseksi kannessa olevan aukon kautta. Rinnakkaiset näytteet sijoitettiin kahteen kaappiin, joiden lämpötila pidettiin mahdollisimman vakiona $20 \pm 1^{\circ} \mathrm{C}$.

Ruohosta otettiin näytteet rehunteon yhteydessä ja säilörehuista siilojen avauksen yhteydessä. Raaka-aineesta määritettiin kuiva-aine, tuhka, kokonais- ja liukoinen typpi, neutraalidertergenttikuitu (NDF), pelkistävät sokerit, puskurikapasiteetti ja in vitro-sulavuus sellulaasimenetelmällä. Säilörehuista määritettiin kuiva-aine, tuhka, pH, maitohappo, haihtuvat rasvahapot (VFA: etikka-, propioni-, voi-, isovoi-, valeriaana-, isovaleriaana- ja kapronihappo), pelkistävät sokerit, etanoli, kokonais-, liukoinen ja ammoniumtyppi. Näytteet analysoitiin MTT:n Eläinravitsemusryhmän laboratoriossa Jokioisilla.

Säilörehujen koostumus, käymislaatu ja aerobinen stabiilisuus testattiin varianssianalyysillä SAS:n GLM proseduurilla. Mallissa oli kuiva-aineen ja säilöntäainekäsittelyn vaikutus sekä kuivaaine x säilöntäainekäsittely -yhdysvaikutus. Säilöntäainekäsittelyjen (ei säilöntäainetta, vetyperoksidinatriumbentsoaatti ja muurahaishappo) väliset erot testattiin parivertailulla käyttäen t-testiä.

\section{Tulokset ja tulosten tarkastelu}

Säilörehun raaka-aineen sulavan orgaanisen aineen pitoisuudet eli D-arvot olivat 68 \% ja 69 \% (KA1 ja KA2). Sulavuus oli kuivemmassa ruohossa hieman korkeampi, mikä saattoi johtua kasvustoeroista, vaikka rehut tehtiin samalta karholta. Vastaavat kuitupitoisuudet (NDF) olivat 557 ja $561 \mathrm{~g} / \mathrm{kg}$ ka. Sokeripitoisuus oli lyhyemmän aikaa esikuivatussa ruohossa suurempi kuin pidempään kuivatussa ruohossa (121 vs $105 \mathrm{~g} / \mathrm{kg} \mathrm{ka),} \mathrm{mikä} \mathrm{on} \mathrm{todettu} \mathrm{myös} \mathrm{aiemmissa} \mathrm{tutkimuksissa} \mathrm{(Heikkilä} \mathrm{ym.} \mathrm{2002).}$ 


\section{Säilörehun koostumus ja käymislaatu}

Säilörehun kuiva-ainepitoisuudet olivat tavoitealueella eli 29 \% ja 44 \%. Tuhkapitoisuus oli hieman suurempi $(\mathrm{P}<0,05)$ koeliuoksella ja ilman säilöntäainetta säilötyissä rehuissa kuin muurahaishapporehussa, mitä voi selittää runsaampi käyminen ja vetyperoksidi-natriumbentsoaattiliuoksessa tuleva pieni natriumlisä. Aistinvaraisesti ja käymislaadultaan kaikki säilörehut olivat hyviä (Taulukot 1 ja 2).

\section{Kuiva-aineen vaikutus}

Suurempi kuiva-ainepitoisuus rajoitti selvästi käymistä kaikissa säilöntäainekäsittelyissä. Kuivemmissa säilörehuissa $\mathrm{pH}$-arvo ja sokeripitoisuus olivat suuremmat $(\mathrm{P}<0,001)$, ja vastaavasti maito- ja etikkahappo- ja etanolipitoisuudet sekä ammoniumtypen osuus kokonaistypestä olivat pienemmät $(\mathrm{P}<0,001)$ kuin tuoreemmissa säilörehuissa. Voihappoa ja isovaleriaanahappoa esiintyi säilörehuissa hyvin vähän. Valeriaanahappoa oli vain hieman kuivemmissa rehuissa ja kapronihappoa yhdessä koeliuosrehun kuivassa näytteessä.

\section{Säilöntäaineen vaikutus}

Vetyperoksidi-natriumbentsoaatti -säilöntäaineella ja ilman säilöntäainetta tehtyjen rehujen välillä ei ollut merkitsevää eroa säilörehun pH:ssa, maitohappo-, propionihappo- ja käymishappojen kokonaispitoisuudessa eikä ammoniumtypen ja liukoisen typen osuudessa kokonaistypestä. Koeliuosrehussa oli hieman vähemmän sokeria ja enemmän etanolia $(\mathrm{P}<0,01)$ kuin ilman säilöntäainetta tehdyssä rehussa ja vaikutus oli suurempi tuoreemmassa rehussa kuin kuivemmassa (yhdysvaikutus $\mathrm{P}<0,05$ ). Rehujen voihappopitoisuus oli merkityksettömän pieni vaikkakin pienempi $(\mathrm{P}<0,05)$ säilöntäaineilla käsitellyissä verrattuna ilman säilöntäainetta tehtyyn rehuun. Muurahaishappo rajoitti tyypillisesti rehujen käymistä lähes kaikkien parametrien kohdalla, jolloin rehussa oli alempi $\mathrm{pH}$, sokeria enemmän, käymishappoja vähemmän ja valkuainen hajonnut vähemmän kuin muilla säilöntäainekäsittelyillä.

\section{Taulukko 1. Säilörehujen koostumus ja käymislaatu}

\begin{tabular}{|c|c|c|c|c|c|c|c|c|c|}
\hline \multirow[b]{2}{*}{ Säilöntäaine } & \multicolumn{3}{|c|}{ Koostumus } & \multicolumn{3}{|c|}{ Käymislaatu } & \multirow[b]{2}{*}{$\begin{array}{l}\text { Eta- } \\
\text { noli }\end{array}$} & \multirow[b]{2}{*}{$\mathrm{NH}_{4}-\mathrm{N}$} & \multirow[b]{2}{*}{$\begin{array}{c}\text { Liukoi- } \\
\text { nen N }\end{array}$} \\
\hline & $\begin{array}{c}\text { Kuiva- } \\
\text { aine }\end{array}$ & Tuhka & $\begin{array}{l}\text { Raaka- } \\
\text { prote- } \\
\text { iini }\end{array}$ & $\mathrm{pH}$ & $\begin{array}{l}\text { Soke- } \\
\text { ri }\end{array}$ & $\begin{array}{l}\text { Maito- } \\
\text { happo }\end{array}$ & & & \\
\hline & $\mathrm{g} / \mathrm{kg}$ & \multicolumn{2}{|c|}{------g/kg ka------ } & & \multicolumn{3}{|c|}{------------g/kg ka------------ } & \multicolumn{2}{|c|}{--------g/kg N------- } \\
\hline \multicolumn{10}{|c|}{ Kuiva-aine $29 \%$} \\
\hline Ei säil.ainetta & 288 & 84,6 & 151 & 4,27 & 46,9 & 70,2 & 9,4 & 61,3 & 701 \\
\hline $\mathrm{H}_{2} \mathrm{O}_{2}+\mathrm{Na}$-bents. & 290 & 84,7 & 153 & 4,22 & 35,5 & 69,1 & 11,6 & 60,7 & 672 \\
\hline Muurahaishappo & 292 & 83,4 & 150 & 4,14 & 86,5 & 33,2 & 8,9 & 26,1 & 622 \\
\hline \multicolumn{10}{|c|}{ Kuiva-aine $44 \%$} \\
\hline Ei säil.ainetta & 445 & 85,0 & 161 & 4,72 & 60,5 & 46,0 & 6,5 & 48,8 & 673 \\
\hline $\mathrm{H}_{2} \mathrm{O}_{2}+\mathrm{Na}$-bents. & 442 & 85,1 & 160 & 4,73 & 58,1 & 43,8 & 7,2 & 48,5 & 679 \\
\hline Muurahaishappo & 444 & 83,0 & 158 & 4,63 & 119,8 & 4,8 & 3,1 & 22,0 & 573 \\
\hline SEM & 1,2 & 0,56 & 1,4 & 0,019 & 2,10 & 1,11 & 0,40 & 0,78 & 6,8 \\
\hline \multicolumn{10}{|c|}{ Tilastollinen merkitsevyys } \\
\hline Kuiva-aine (KA) & $* * *$ & & $* * *$ & $* * *$ & $* * *$ & $* * *$ & $* * *$ & $* * *$ & $* *$ \\
\hline Säilöntäaine & & $*$ & & $* * *$ & $* * *$ & $* * *$ & $* * *$ & $* * *$ & $* * *$ \\
\hline KA*Säil.aine yhd & & & & & $* *$ & & $*$ & $* * *$ & $* *$ \\
\hline \multicolumn{10}{|l|}{ t-testi } \\
\hline $\mathrm{H}_{2} \mathrm{O}_{2}+\mathrm{Na} /$ Ei säil.a & & & & & $* *$ & & $* *$ & & \\
\hline $\mathrm{H}_{2} \mathrm{O}_{2}+\mathrm{Na} / \mathrm{MH}$ & o & * & 0 & $* * *$ & $* * *$ & $* * *$ & $* * *$ & $* * *$ & $* * *$ \\
\hline MH / Ei säil.a & & $*$ & & $* * *$ & $* * *$ & $* * *$ & $* * *$ & $* * *$ & $* * *$ \\
\hline $\begin{array}{l}\text { SEM = keskiarvon } \\
\text { aatti, MH = muural } \\
\text { Tilastollinen testau } \\
\text { säilöntäainekäsittel } \\
\text { Merkitsevyys: ei m }\end{array}$ & $\begin{array}{l}\text { eskivirhe } \\
\text { ishappo } \\
\text { KA = k } \\
\text { yhdysva } \\
\text { kintää, e }\end{array}$ & $\begin{array}{l}\text { Ei säil.a } \\
\text { liva-aine, } \\
\text { kutus, Ei } \\
\text { merkitse }\end{array}$ & $\begin{array}{l}\text { E Ei säilö } \\
\text { Säil.aine } \\
\text { äil.a = Ei } \\
\text { ( }(P>0,10)\end{array}$ & $\begin{array}{l}\text { äainetta } \\
\text { Säilönt } \\
\text { äilöntäai } \\
0 \text { P }<0.1\end{array}$ & $\begin{array}{l}\mathrm{H}_{2} \mathrm{O}_{2}+1 \\
\text { lainekäs } \\
\text { netta } \\
* \mathrm{P}<0\end{array}$ & $\begin{array}{l}\text { a-bents. = } \\
\text { tely, KA* }\end{array}$ & $\begin{array}{l}\text { etyper } \\
\text { äil.aine }\end{array}$ & $\begin{array}{l}\text { ksidi + na } \\
\text { yhd }=\text { kui } \\
<0,001\end{array}$ & $\begin{array}{l}\text { iumbents } \\
\text { a-aineen }\end{array}$ \\
\hline
\end{tabular}


Taulukko 2. Säilörehujen haihtuvat rasvahapot ja käymishapot yhteensä

\begin{tabular}{|c|c|c|c|c|c|c|c|}
\hline Säilöntäaine & $\begin{array}{c}\text { Etikka- } \\
\text { happo }\end{array}$ & $\begin{array}{l}\text { Propioni- } \\
\text { happo }\end{array}$ & $\begin{array}{l}\text { Voi- } \\
\text { happo }\end{array}$ & $\begin{array}{c}\text { Isovale- } \\
\text { riaana- } \\
\text { happo }\end{array}$ & $\begin{array}{c}\text { Valeri- } \\
\text { aana- } \\
\text { happo }\end{array}$ & $\begin{array}{c}\text { Haihtuvat } \\
\text { rasva- } \\
\text { hapot }{ }^{1)} \\
\text { yhteensä }\end{array}$ & $\begin{array}{c}\text { Käymis- } \\
\text { hapot } \\
\text { yhteensä } \\
2 \text { ) }\end{array}$ \\
\hline \multicolumn{8}{|c|}{-------------------------------------------------g/kg ka--------------------------------------------- } \\
\hline \multicolumn{8}{|c|}{ Kuiva-aine $29 \%$} \\
\hline Ei säil.ainetta & 17,3 & 0,14 & 0,16 & 0,10 & 0,00 & 17,7 & 87,9 \\
\hline $\mathrm{H}_{2} \mathrm{O}_{2}+\mathrm{Na}$-bentsoaati & 19,1 & 0,22 & 0,12 & 0,11 & 0,00 & 19,6 & 88,7 \\
\hline Muurahaishappo & 9,7 & 0,13 & 0,12 & 0,10 & 0,00 & 10,0 & 43,2 \\
\hline \multicolumn{8}{|c|}{ Kuiva-aine $44 \%$} \\
\hline Ei säil.ainetta & 11,7 & 0,10 & 0,19 & 0,08 & 0,01 & 12,0 & 58,1 \\
\hline $\mathrm{H}_{2} \mathrm{O}_{2}+$ Na-bentsoaatti & 10,9 & 0,09 & 0,14 & 0,11 & 0,02 & 11,4 & 55,1 \\
\hline Muurahaishappo & 5,4 & 0,13 & 0,15 & 0,13 & 0,07 & 5,9 & 10,7 \\
\hline SEM & 0,28 & 0,026 & 0,017 & 0,010 & 0,021 & 0,29 & 1,21 \\
\hline \multicolumn{8}{|l|}{ Tilastollinen merkitsevyys } \\
\hline Kuiva-aine (KA) & $* * *$ & $*$ & & & 0 & $* * *$ & $* * *$ \\
\hline Säilöntäaine & $* * *$ & & $*$ & $*$ & & $* * *$ & $* * *$ \\
\hline $\begin{array}{l}\text { KA*Säil.aine yhdysvaik. } \\
\text { t-testi }\end{array}$ & $* * *$ & o & & $*$ & & $* * *$ & \\
\hline $\mathrm{H}_{2} \mathrm{O}_{2}+$ Na-bents. / Ei säil.a & 0 & & $*$ & 0 & & 0 & \\
\hline $\mathrm{H}_{2} \mathrm{O}_{2}+$ Na-bents. / MH & $* * *$ & & & & & $* * *$ & $* * *$ \\
\hline MH / Ei säil.a & $* * *$ & & $*$ & $*$ & & $* * *$ & $* * *$ \\
\hline
\end{tabular}

${ }^{1)}$ Haihtuvat rasvahapot (VFA: volatile fatty acids): etikka-, propioni-, voi-, isovoi-, isovaleriaana-, valeriaana- ja kapronihappo. Isovoihappoa ei esiintynyt missään näytteessä.

${ }^{2)}$ Käymishapot yhteensä = haihtuvat rasvahapot + maitohappo

SEM = keskiarvon keskivirhe, Ei säil.a = Ei säilöntäainetta, $\mathrm{H}_{2} \mathrm{O}_{2}+$ Na-bents. = vetyperoksidi + natriumbentsoaatti, $\mathrm{MH}=$ muurahaishappo

Tilastollinen testaus: KA = kuiva-aine, Säil.aine = Säilöntäainekäsittely, KA*Säil.aine yhd = kuiva-aineen ja säilöntäainekäsittelyn yhdysvaikutus, Ei säil.a $=$ Ei säilöntäainetta

Merkitsevyys: ei merkintää, ei merkitsevä $(\mathrm{P}>0,10),{ }^{\mathrm{O}} \mathrm{P}<0,10, * \mathrm{P}<0,05, * * \mathrm{P}<0,01, * * * \mathrm{P}<0,001$

Kaikki tutkitut säilörehut olivat laadultaan hyviä säilörehun laatuvaatimusten mukaan (Taulukko 3, MMM päätös 48/1999), joita käytettiin aiemmin Suomessa kansallisessa säilöntäaineiden hyväksymismenettelyssä ja nyt vapaaehtoisen nurmirehun säilöntäaineen maatilatestauksen arviointikriteerinä.

Taulukko 3. Säilörehun laatuvaatimusten laatutekijöiden ylärajat eri säilörehun laatuluokissa verrattuna tutkittujen säilörehujen tuloksiin tuoreessa säilörehussa

\begin{tabular}{|c|c|c|c|c|c|c|c|c|}
\hline \multirow{3}{*}{ Laatutekijä } & \multirow{2}{*}{\multicolumn{2}{|c|}{$\begin{array}{l}\text { Säilörehun } \\
\text { laatuluokka }\end{array}$}} & \multicolumn{3}{|c|}{ Kuiva-aine $29 \%$} & \multicolumn{3}{|c|}{ Kuiva-aine $44 \%$} \\
\hline & & & \multirow{2}{*}{$\begin{array}{l}\text { Ei säil. } \\
\text { ainetta }\end{array}$} & \multirow{2}{*}{$\begin{array}{l}\mathrm{H}_{2} \mathrm{O}_{2}+ \\
\mathrm{Na}- \\
\text { bents. }\end{array}$} & \multirow{2}{*}{$\begin{array}{l}\text { Muura- } \\
\text { hais- } \\
\text { happo }\end{array}$} & \multirow{2}{*}{$\begin{array}{l}\text { Ei säil. } \\
\text { ainetta }\end{array}$} & \multirow{2}{*}{$\begin{array}{l}\mathrm{H}_{2} \mathrm{O}_{2}+ \\
\mathrm{Na}- \\
\text { bents. }\end{array}$} & \multirow{2}{*}{$\begin{array}{l}\text { Muura- } \\
\text { hais- } \\
\text { happo }\end{array}$} \\
\hline & Hyvä & $\begin{array}{l}\text { Tyydyt- } \\
\text { tävä }\end{array}$ & & & & & & \\
\hline Maitohappo (g/kg) & 25,0 & $\begin{array}{l}\text { ei rajoi- } \\
\text { tusta }\end{array}$ & 20,3 & 20,0 & 9,7 & 20,5 & 19,3 & 2,1 \\
\hline Etikkahappo (g/kg) & $6,0^{2}$ & $10,0^{2}$ & 5,0 & 5,5 & 2,8 & 5,2 & 4,8 & 2,4 \\
\hline Voihappo (g/kg) & 1,0 & 1,0 & 0,04 & 0,04 & 0,04 & 0,08 & 0,06 & 0,07 \\
\hline $\mathrm{NH}_{4}-\mathrm{N} /$ kok.N $(\mathrm{g} / \mathrm{kg})^{1)}$ & $80^{2}$ & $120^{2}$ & 61 & 61 & 26 & 49 & 49 & 22 \\
\hline Happamuus $(\mathrm{pH})^{2)}$ & $4,20^{3}$ & $4,20^{3}$ & 4,27 & 4,22 & 4,14 & 4,72 & 4,73 & 4,63 \\
\hline
\end{tabular}

${ }^{1)}$ Ammoniumtyppi kokonaistypestä, g/kg

2) Poikkeukset pH:n osalta: Jos säilörehun kuiva-ainepitoisuus on 275 - 450 g/kg, pH voi sekä hyvän että tyydyttävän säilörehun luokassa ylittää arvon 4,20.

Jokaisessa luokassa pH voi olla 0,2 yksikköä korkeampi, jos sokeripitoisuus on vähintään 30 g/kg kuiva-ainetta. Näiden sääntöjen mukaan tuoreemman (kuiva-aine 29 \%) hyvän rehun pH voisi olla 4,45 ja kuivemman (kuivaaine $44 \%) \mathrm{pH}$ voisi olla 5. 


\section{Aerobinen stabiilisuus}

Vetyperoksidi-natriumbentsoaattiliuos paransi merkitsevästi säilörehun aerobista stabiilisuutta ilman säilöntäainetta ja muurahaishapolla tehtyyn säilörehuun verrattuna vaikutuksen ollessa suurempi tuoreemmassa (ka 29 \%) säilörehussa kuin kuivemmassa (ka 44 \%) rehussa. Tuoreempi säilörehu lämpeni nopeammin ja enemmän kuin kuivempi säilörehu kaikilla säilöntäainekäsittelyillä. Ilman säilöntäainetta tehty tuoreempi rehu alkoi lämmetä kolmen vuorokauden päästä siilojen avauksesta ja vetyperoksidi-natriumbentsoaattiliuoksella säilötty rehu noin neljä vuorokautta myöhemmin muurahaishapporehun lämpenemisherkkyyden ollessa niiden välillä. Kuvioissa 1 ja 2 on esitetty kumulatiivinen lämpeneminen. Aerobisen stabiilisuuden paraneminen vetyperoksidi-natriumbentsoaattiliuosta käytettäessä perustui todennäköisesti natriumbentsoaattiin, jota tuli rehuun säilöntäaineessa 750 g tonnia kohti säilöntäaineen annostustasolla 5 l/t.

\section{Johtopäätökset}

Kaikilla säilöntäainekäsittelyillä tehdyt säilörehut olivat käymislaadultaan hyviä, myös ilman säilöntäainetta tehty säilörehu. Vetyperoksidi-natriumbentsoaatti -säilöntäaine ei kuitenkaan parantanut säilörehun käymislaatua ilman säilöntäainetta tehtyyn rehuun verrattuna. Muurahaishapporehut olivat käymislaadultaan molempia muita rehuja parempia, tyypillisesti rajoittuneesti käyneitä. Sen sijaan säilörehun aerobista stabiilisuutta siilojen avaamisen jälkeen vetyperoksidi-natriumbentsoaattiliuos paransi merkitsevästi verrattuna ilman säilöntäainetta ja muurahaishapolla säilöttyihin rehuihin. Vaikutus oli suurempi tuoreemmassa rehussa kuin kuivemmassa. Rehun korkeampi kuiva-ainepitoisuus (29 vs 44 \%) vähensi käymistä sekä lämpenemisherkkyyttä kaikissa rehuissa. Vetyperoksidi-natriumbentsoaattisäilöntäaineen aerobista stabiilisuutta parantava vaikutus johtui todennäköisesti natriumbentsoaatista.

\section{Kuviot 1 ja 2. Säilörehujen aerobinen stabiilisuus kumulatiivisena lämpenemisenä kuiva-aineittain ja säilöntäainekäsittelyittäin}

(näytteen lämpötilan ja kaapin lämpötilan $\left( \pm 20^{\mathrm{O}} \mathrm{C}\right)$ erotusten summa, vuorokausikeskiarvot)

\section{Kuvio 1}

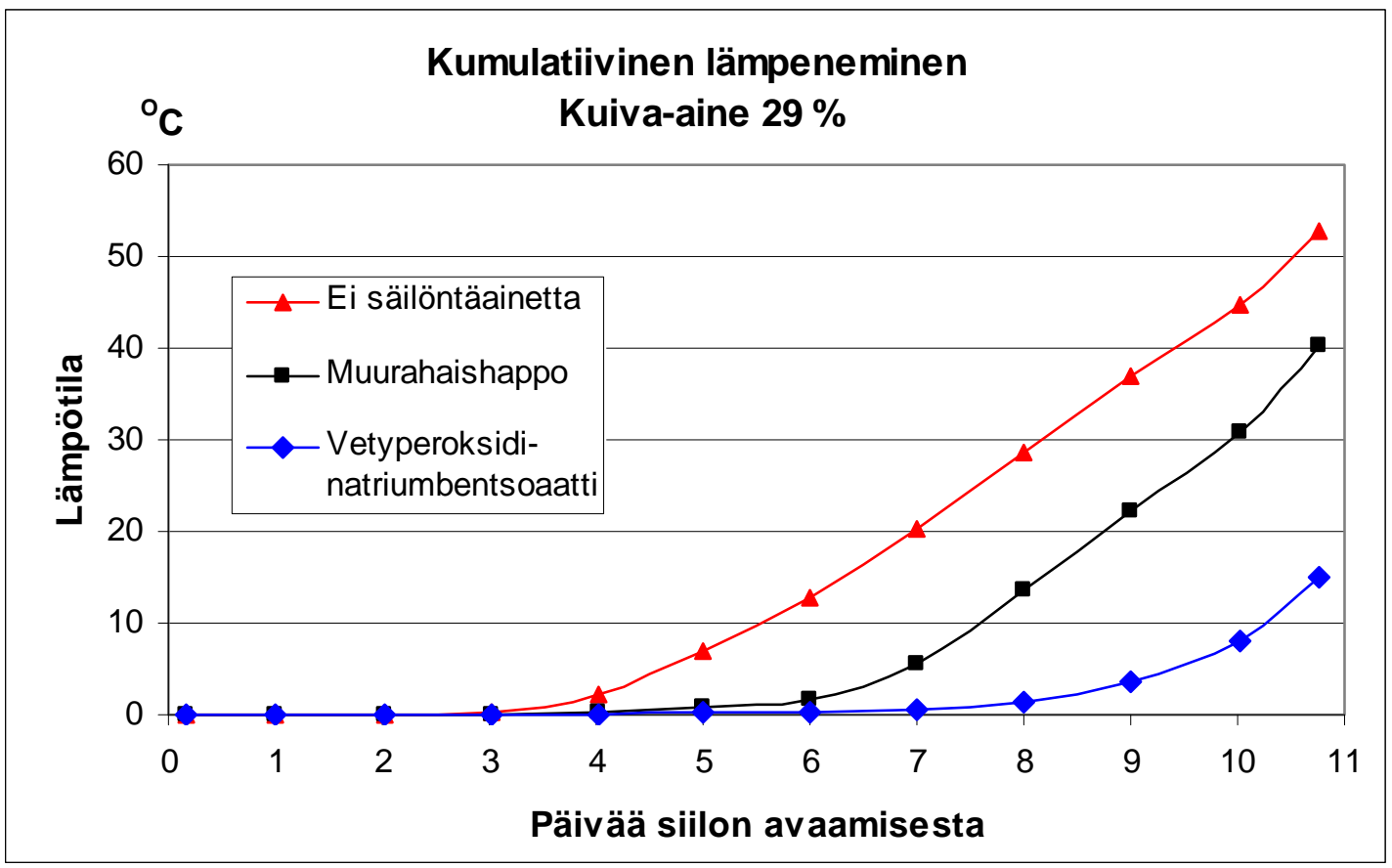




\section{Kuvio 2}

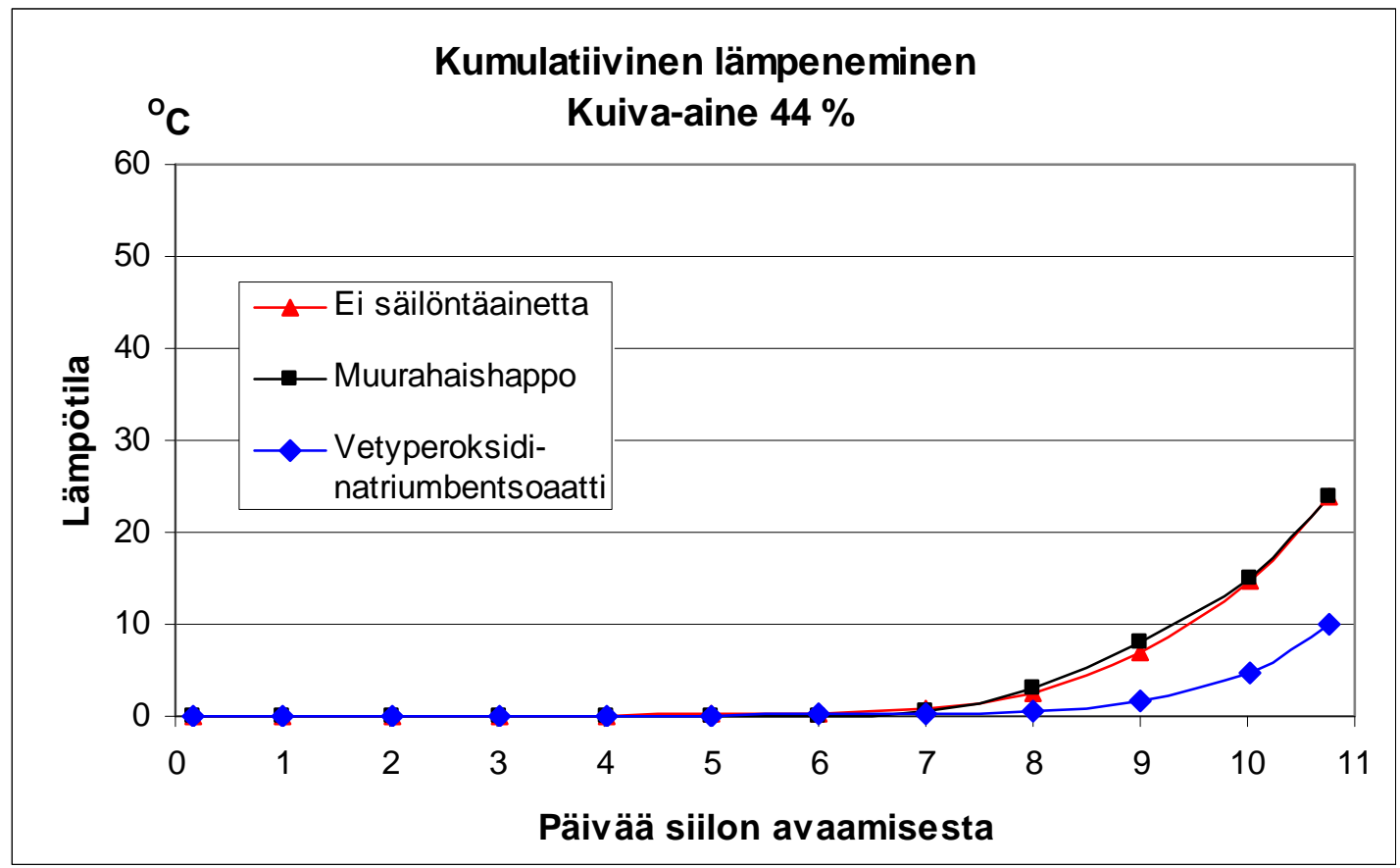

\section{Kirjallisuus}

EU-lisäainerekisteri. Community Register of Feed Additives, pursuant to Regulation (EC) No 1831/2003, Appendixes 3 \& 4. Annex: List of additives 22.12.2009, edition 66. p. 61. Viitattu 2.1,2010.

http://ec.europa.eu/food/food/animalnutrition/feedadditives/comm_register_feed_additives_1831-03.pdf

Evira 2009. Lisäaineiden rekisteri.

http://www.evira.fi/portal/fi/kasvintuotanto_ja_rehut/rehut/rehun_lisaaineet/rehun_lisaaineiden_rekisteri/

Heikkilä, T., Jaakkola, S., Saarisalo, E., Suokannas, A., Helminen, J. 2002. Kuivatusajan, säilöntäaineen ja muovikerrosten vaikutus pyöröpaalisäilörehun laatuun. In: toim. Marketta Rinne. Maataloustieteen Päivät 2002 : Kotieläintiede, 9.-10.1.2002 Viikki, Helsinki. Maaseutukeskusten Liiton julkaisuja 977: p. 66-70.

MMM 1999. Maa- ja metsätalousministeriön päätös tuoreen rehukasvin säilöntäaineista Nro 48/1999.

http://wwwb.mmm.fi/el/laki/kara/_/rehu_ja_luomujaosto/MMMp99/p990048.doc

Saarisalo, E., Jalava, T., Skyttä, E. , Haikara, A. \& Jaakkola, S. 2006. Effect of lactic acid bacteria inoculants, formic acid, potassium sorbate and sodium benzoate on fermentation quality and aerobic stability of wilted grass silage. Agricultural and Food Science 15, 3: 185-199.

Woolford, M.K. 1975. Microbiological screening of food preservatives, cold sterilants and specific antimicrobial agents as potential silage additives. Journal of the Science of Food and Agriculture 26: 229-237. 